\title{
Field experiments on the colonization of meiofauna into sediment depressions
}

\author{
Bin Sun, John W. Fleeger \\ Department of Zoology and Physiology, Louisiana State University Baton Rouge, Louisiana 70803, USA
}

\begin{abstract}
An investigation of meiofaunal colonization into mimic sediment depressions was conducted in a controlled, $72 \mathrm{~h}$ field experiment. Artificial depressions were constructed with variable aspect ratios (different diameter and depth combinations) to mimic natural depressions, but with predictable hydrodynamic characteristics. Colonization into these depressions and into surrounding nondepression areas was compared. Meiofaunal life style, i.e epibenthic or burrowing, influenced the results. Densities of epibenthic copepods inside depressions were much higher than in non-depression areas, and density increased with increasing depression aspect ratio, suggesting that settlement is greater in areas of reduced shear stress. Depression aspect ratio appears to be a good predictor of the density of epibenthic meiofauna in field depressions. The density of burrowers, e.g. nematodes and some copepods, in depressions depended (inversely) on depression diameter rather than aspect ratio. and densities inside depressions were much lower than in surrounding non-depression areas. Further, burrower density in depressions was related to depression circumference/area ratio. Our results suggest that settlement of epibenthic meiofauna into depressions occurs primarily through water-column transport, while burrowers most likely colonize either by crawling along the sediment surface or by disturbance-induced suspension of the flocculent layer along the sediment-water interface.
\end{abstract}

KEY WORDS: Colonization - Sediment depression · Meiofauna

\section{INTRODUCTION}

Topographic features like pits and depressions are prevalent and abundant features in muddy sediments (Sun et al. 1993). Many studies have found a positive association between sediment depressions and the abundance of meiofauna, especially epibenthic copepods (Reidenauer \& Thistle 1981, Savidge \& Taghon 1988, DePatra \& Levin 1989, Sun et al. 1993). Although natural depressions are relatively easy to identify and sample in air-exposed sediments, they are not ideal experimental units. The dimensions of depressions are difficult to quantify in the field, and they have an irregular shape that unpredictably affects biologically meaningful physical conditions of the depressions. For example, the aspect ratio, the ratio of height to diameter, will vary in any natural collection of depressions and can affect deposition and entrainment. Also, the history of depressions greatly varies in natural conditions. Some pits are long-lived (those associated with macrofauna burrows), while others are highly ephemeral (Sun et al. 1993). Fortunately however, depressions are relatively easy to mimic, and controlled experimentation is possible.

Recent studies indicate that movement through the water column is very important to dispersal by meiofauna, especially epibenthic copepods (Hagerman \& Rieger 1981, Chandler \& Fleeger 1983, Palmer \& Gust 1985, Palmer 1988). Epibenthic copepods live at the sediment-water interface and make frequent forays in the near-bottom water (Aromonies 1988a, b). Some epibenthic copepods have also been considered to be hyperbenthic (McCall 1992a, b). Logically, the abundance of epibenthic meiofauna in or on sediment may depend heavily on the process of resettlement or recolonization of individuals from the water column. However, less is known about dispersal processes of another functional group - infaunal burrowers. Most nematodes and some harpacticoids live deeper in the sediment and rarely actively enter the water column 
(Palmer 1988). Their abundance in the water column is much reduced compared to their sediment abundance (Sibert 1981). The different life style of this functional group may cause a different response to sediment topography, and even dispersal in general, because dispersal mechanisms may differ dramatically from epibenthic meiofauna (Fegley 1987, Palmer 1988).

A body of theoretical and experimental research has been conducted on the entry of macrofaunal larvae into suspended settlement traps (Lau 1979, Butman 1986, 1989, Butman et al. 1988, Yund et al. 1991). This research suggests that hydrodynamic forces differ among traps with different aspect ratios. Hydrodynamic forces acting on a regular pit or depression may also be predicted from these settling trap studies and can be empirically observed. Given their small body size, settlement of water-born meiofauna into depressions of different aspect ratios may also be a function of ithe hydrodynamic regime. Previous studies indicated that either passive or both passive and active settlement occurs for epibenthic meiofauna (Eckman 1983, Kern \& Taghon 1986, Savidge \& Taghon 1988, Fegley 1988, Palmer 1992).

Given the use of meiofaunal recolonization patterns in studies of pollution effects (Alongi et al. 1983, Decker \& Fleeger 1984, Palmer et al. 1988, Spies et al. 1988, Feder et al. 1990), it is important to have a basic understanding of the mechanisms of colonization of meiofauna. In the present study, artificial depressions were used with 6 aspect ratios in a field recolonization study. The objectives were to investigate the response of functional groups of meiofauna to the effects of time of colonization, depression size and aspect ratio on colonization and abundance.

\section{MATERIALS AND METHODS}

Study area. The study area, located in Terrebonne Parish near Cocodrie, Louisiana, USA $\left(29^{\circ} 15^{\prime} \mathrm{N}, 91^{\circ}\right.$ $21^{\prime} \mathrm{W}$ ), is characterized as a salt marsh dominated by the cordgrass Spartina alterniflora Loisel. The mudflat site $(20 \times 4 \mathrm{~m})$ is an intertidal area between the $S$. alterniflora marsh and a well-travelled bayou. Sediments are composed predominantly of silts and clays and are very similar to the sediment described by Chandler \& Fleeger (1983). This site has been well described physically and biologically with a considerable ecological baseline of the meiofaunal assemblage (Phillips \& Fleeger 1985, Decho \& Fleeger 1988, Sun \& Fleeger 1991). The tidal regime is typically diurnal and water movement is dominantly affected by wind direction and intensity (Childers et al. 1990). However, the site is commonly exposed to disturbances from wakes of small boat traffic. The frequency of passing boats varies from season to season and the intensity of wake disturbarice depends on boat size and speed.

To determine the characteristics of water movement at our experimental site, flow measurements, at $5 \mathrm{~cm}$ above the bottom, were taken during an ebbing and the late stages of a flooding tide (close to slack tide). We also measured current velocities from wakes during small boat passage. All current velocities were measured just before the beginning of the field experiment by Montedoro-Whitney flow meter, and 4 to 5 repeat measurements were always taken.

Sampling. During low tide on 3 August 1991, 60 experiment units were established acrass the longitudinal axis of the mudflat. The distance between any 2 units was about $0.4 \mathrm{~m}$. The units consisted of sedimentation/bed-load traps adapted from Fegley (1988), except that plastic vials were filled to specific levels with defaunated sediment to alter the depth of the depression (Fig. 1). The unit resembled a doughnut in that there were 2 parts to each unit: a centered depression mimic and a surrounding circular non-depression area buried flush with the ambient sediments. Six aspect ratios of depression mimics consisted of a combination of large- and small-diameter plastic vials (32 mm i.d., L, and $14 \mathrm{~mm}$ i.d., S). Vials were $5.5 \mathrm{~cm}$ in total height, and filled with defaunated sediment to 3 different working depths $(3,6,10 \mathrm{~mm})$. The values of 6 aspect ratios (combinations of 2 diameters and 3 depths) were 0.09 (L3: large diameter, $3 \mathrm{~mm}$ depth), 0.18 (L6), 0.29 (L10), 0.21 (S3: small diameter), 0.43 (S6), and 0.71 (S10). The depth was the distance from the mouth of the vial to the surface of the defaunated sediment. The non-depression area consisted of defaunated sediment (as in the vials) that surrounded the depression mimic. Sediment was collected from the study area several weeks prior to the colonization

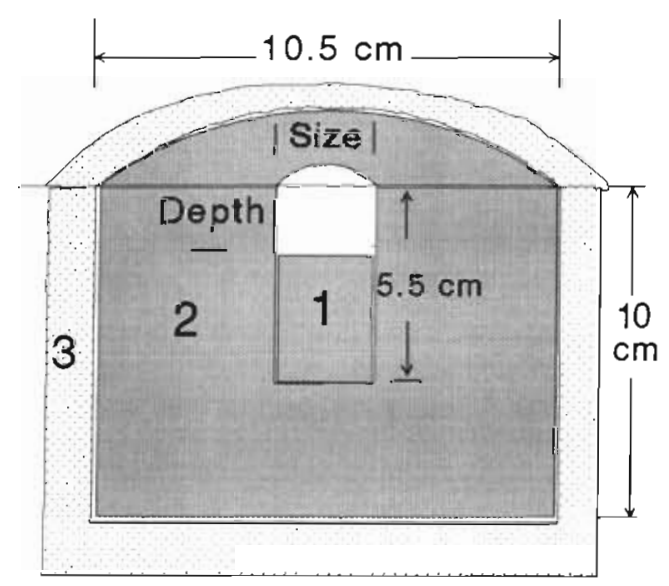

Fig. 1. Schematic diagram of the sedimentation/bed-load colonization unit. (1) Azoic sediment in depression; (2) azoic sediment in non-depression area (3) ambient sediment 
study. The sediment was washed through $0.5 \mathrm{~mm}$ sieve with distilled water and heated at $100^{\circ} \mathrm{C}$ for at least $24 \mathrm{~h}$ to kill and remove meiofauna. Defaunated sediment was checked for meiofauna after $2 \mathrm{wk}$, and no animals were found. Because we also considered recolonization time (samples were collected at 24,48 , and $72 \mathrm{~h}$ after initiation) as an experimental treatment, there were 18 time by aspect-ratio combinations. Each combination was replicated in triplicate. The total experimental units numbered 54 . Six additional units (with 6 different diameter and depth combinations) were constructed as backups, in case some units were lost.

To place the colonization units on the mudflat, a circular $10.5 \mathrm{~cm}$ i.d. $\times 15 \mathrm{~cm}$ high thin metal ring was pushed vertically into the sediment during low tide while air exposed. Ambient sediment inside the ring was excavated down to about $10 \mathrm{~cm}$ and replaced with defaunated sediment. A depression mimic was then carefully placed inside the defaunated sediment at the center of the excavation. Care was made to ensure that the surface of each vial was flush with the defaunatedsediment surface. Units were marked by placing a bamboo stick ( $2 \mathrm{~mm}$ i.d.) at the edge of the unit. Different colors and shapes were associated with the marking stick for the 6 diameter-depth combinations so they could be easily recognized. Disturbance associated with sample collection was avoided by use of a small foot bridge previously constructed over the mudflat.

Samples were collected only at low tide, 24, 48, and $72 \mathrm{~h}$ after initiation. For each collection, 3 replicates for each of the 6 diameter-depth combinations were randomly chosen. During sampling, depression mimics were carefully lifted by hand and removed to a $150 \mathrm{ml}$ jar. If the surface of the depression mimic was not flush with the surface of the sediment, the unit was abandoned. Non-depression areas were sampled with a syringe-style corer (1.2 mm i.d.), modified by removing both ends. Two samples were taken in the non-depression areas and the top $3 \mathrm{~cm}$ of sediment was retained in a $50 \mathrm{ml} \mathrm{jar}$ and preserved with $5 \%$ formalin and Rose Bengal. In order to compare the species composition and population structure between the defaunated and ambient sediment, 5 samples were collected during each sampling period from the surrounding, undisturbed ambient sediment with the same syringe corer.

In the laboratory, the sediment inside depression mimic vials was removed and preserved in formalin with Rose Bengal. All samples were treated by sonication and sieving. Copepods retained on a $63 \mu \mathrm{m}$ sieve were identified to species (sex and development stages were recorded) and enumerated. Nematodes were identified only to major taxon.

Statistical analysis. Data were standardized to individuals per square centimeter (ind $\mathrm{cm}^{-2}$ ) for each observation. Residual analyses for normality were performed after data transformation, $\ln (x+1)$. The result indicated an approximate normality for all data analyzed $(W>0.96, n=102, p>0.2)$ (Shapiro \& Wilk 1965).

A 2-way ANOVA was employed to analyze meiofauna density. A split-plot model was adopted with time and depression aspect ratio as main effects, and treatment effect (depression vs non-depression) as a subplot. Because non-depressions have no aspect-ratio variation, the main plot was ignored. Only subplot effects were analyzed. The Tukey multiple comparison test was used to detect time and aspect-ratio effects with each of the 2 treatments (depression vs nondepression).

\section{RESULTS}

Current velocities were measured on a day with minimal wind. Water movement toward the mudflat (perpendicular to the bayou) was slow, ranging from 1.2 to $3.0 \mathrm{~cm} \mathrm{~s}^{-1}$ during both an ebbing and the late stages of a flooding tide. Current velocities along the mudflat (parallel to the bayou) were slightly higher, 2.8 to $6.0 \mathrm{~cm} \mathrm{~s}^{-1}$ during both tide stages. The maximum water movement toward the mudflat was caused by small boat passage. The water current velocities from wakes reached 8 to $15 \mathrm{~cm} \mathrm{~s}^{-1}$. Weather conditions were constant during the course of the experiment, and we assume that current velocities had similar values at similar times among different days.

Of the 60 recolonization units, 3 were destroyed by small mammals and 6 did not meet the experimental requirement, i.e. the top surface was not flush with ambient sediment. During recolonization, the original aspect ratios of all depressions changed because of sedimentation. Sedimentation into the depressions from ambient sediment varied among treatments and replicates, but the deeper treatments received more sediment than shallower treatments.

Only nematodes and meiobenthic copepods were counted, although polychaete larvae and other rare meiofauna were found (in densities too low for analysis). Of the copepods, 6 harpacticoid and 1 cyclopoid species were found in the defaunated sediment. Two harpacticoids, Cletocamptus deitersi (Richard) and Coullana sp. (formerly called Scottolana canadensis in Louisiana citations), were dominant and comprised $85.7 \%$ of total abundance of copepods. Halicyclops coulli Herbst was also abundant in depressions (Table 1). These dominant species are capable epibenthic swimmers (Sun pers. obs., Radziejewska unpubl. data) and are common in emergence and sediment trap samples from Louisiana marshes (McCall 1992b). In addition, burrowing meiofauna including nema- 
Table 1. Mean copepod species and nematode densities (mean \pm standard deviation: ind. $\mathrm{cm}^{-2}$ i sample sizes are also given) from depression, non-depression and ambient sediments. Life style designations are given (nematodes are considered to be burrowers; see text)

\begin{tabular}{|c|c|c|c|}
\hline Species & $\begin{array}{c}\text { Depression } \\
\quad(n=51)\end{array}$ & $\begin{array}{l}\text { Non-depression } \\
\quad(n=51)\end{array}$ & $\begin{array}{l}\text { Ambient } \\
(\mathrm{n}=5)\end{array}$ \\
\hline \multicolumn{4}{|l|}{ Epibenthic copepods } \\
\hline Cletocamptus deitersi & $16.7 \pm 10.7$ & $6.7 \pm 3.6$ & $23.9 \pm 13.4$ \\
\hline Coullanasp. & $7.4 \pm 6.1$ & $2.1 \pm 2.0$ & $2.4 \pm 1.9$ \\
\hline Halicyclops coulli & $1.9 \pm 2.5$ & $0.5 \pm 1.1$ & $0.1 \pm 0.4$ \\
\hline \multicolumn{4}{|l|}{ Tube-building copepod } \\
\hline Pseudostenhelia wellsi & $0.3 \pm 0.5$ & $0.6 \pm 0.8$ & $2.7 \pm 2.1$ \\
\hline \multicolumn{4}{|l|}{ Burrowing copepod } \\
\hline Nannopus palustris & $0.5 \pm 1.3$ & $0.7 \pm 0.9$ & $2.4 \pm 2.7$ \\
\hline Total copepods & $28.5 \pm 14.3$ & $9.9 \pm 4.4$ & $29.3 \pm 16.3$ \\
\hline Total nematodes & $14.8 \pm 11.1$ & $21.3 \pm 7.5$ & $213.4 \pm 87.6$ \\
\hline
\end{tabular}

todes and harpacticoids [Pseudostenhelia wellsi Coull \& Fleegeı is a iube-builder (Chandler \& Fleeger 1984) and Nannopus palustris Brady is a subsurface burrower (Sun pers. obs.)] were well represented, but sometimes in low densities.

Comparisons of total abundance among different groups and copepod species indicated a functionalgroup response to defaunated sediment. There were 2 statistically significant patterns detected using ANOVA (Tables 2 \& 3). Firstly, epibenthic copepods such as Coullana sp., Halicyclops coulli and total harpacticoids were much higher in mean density in depressions compared to ambient (natural) sediment (Fig. 2). Further, within defaunated sediment, statistically significant higher abundances were found in depressions than non-depression areas for these epibenthic species (Tables 1 \& 2). On the other hand, burrowers or tube-dwellers such as total nematodes and the harpacticoids Pseudostenhelia wellsi (a tube dweller), and Nannopus palustris (a burrower) displayed a much lower density in defaunated sediment than ambient sediment and a lower density in depressions than non-depressions. Cletocamptus deitersi was intermediate; its mean density in depression areas was higher than in non-depression areas, but lower than ambient areas. Furthermore, both responses, for depressions and non-depressions, were consistent through the ANOVA main effects (Table 3, Fig. 3). For example, total copepods, C. deitersi, and Coullana sp. had consistently higher abundance and total nematodes had consistently lower abundance in depressions through different collection times and aspect-ratio treatments (Fig. 3). Demographic patterns were also evident for epibenthic species (Fig. 4). Significantly more males and copepodites of Coullana sp. colonized defaunated sediment (1-way ANOVA, $n=102$, $p<$

Table 2. Two-way ANOVA results for the treatment (Depression vs Non-depression) (TRT) and the interactions of TRT $\times$ Time and TRT $\times$ Aspect ratio (AR). The experiment was conducted as a split-plot design with time and aspect-ratio effects as main plot and treatment (depression vs non-depression) as subplot (main plot effects were ignored, see statistical analysis in 'Materials and Methods' for details)

\begin{tabular}{|c|c|c|c|c|c|}
\hline \multirow[t]{2}{*}{ Source of variation } & \multirow[t]{2}{*}{$\mathrm{df}$} & \multicolumn{4}{|c|}{$F$-value } \\
\hline & & $\begin{array}{c}\text { Cletocamptus } \\
\text { deitersi }\end{array}$ & Coullana sp. & Total copepods & Total nematodes \\
\hline Time & 2 & $12.01 \cdots$ & $14.30^{\cdots}$ & $19.13^{\cdots}$ & $42.36^{\prime \prime}$ \\
\hline Aspect ratio (AR) & 5 & 0.97 & 1.31 & $2.91^{\circ}$ & $8.98 \cdots$ \\
\hline Time $\times A R$ & 10 & 1.07 & $2.57^{\circ}$ & 0.98 & 0.99 \\
\hline Error I & 33 & $3.07^{\cdots}$ & 1.78 & $2.22^{\circ}$ & 1.19 \\
\hline Treatment (TRT) & 1 & $169.94^{\cdots}$ & $119.59 \cdot$ & $328.40^{\circ}$ & $63.47 \cdots$ \\
\hline TRT $\times$ Time & 2 & 0.14 & $7.80^{\cdots}$ & 0.88 & $5.52 \cdots$ \\
\hline $\mathrm{TRT} \times \mathrm{AR}$ & 5 & $3.67^{\circ}$ & $4.34 \cdots$ & $8.42 \cdots$ & $7.78 \cdots$ \\
\hline TRT $\times$ Time $\times$ AR & 10 & 1.75 & 0.49 & 0.94 & 0.91 \\
\hline Error II & 33 & & & & \\
\hline$" p<0.05_{i} \cdot p<0.01$ & & & & & \\
\hline
\end{tabular}


Table 3. Tukey multiple comparison of mean Cletocamptus deitersi, Coullana sp., total copepods, and total nematodes for treatment (Depression vs Non-depression) $\times$ Time, Treatment $\times$ Aspect ratio. For each comparison, means that do not share a letter are significantly different from one another $(p<0.05)$. Data were transformed by $\ln (x+1)$

\begin{tabular}{|c|c|c|c|c|c|}
\hline Treatment & & Cletocamptus deitersi & Coullanasp. & Total copepods & Total nematodes \\
\hline \multicolumn{6}{|l|}{ Depression } \\
\hline \multirow[t]{3}{*}{$\times$ Time } & $24 \mathrm{~h}$ & $2.38 \mathrm{a}$ & $1.43 \mathrm{a}$ & $2.92 \mathrm{a}$ & $2.07 \mathrm{a}$ \\
\hline & $48 \mathrm{~h}$ & $2.99 \mathrm{~b}$ & $2.31 \mathrm{~b}$ & $3.54 \mathrm{~b}$ & $2.77 \mathrm{~b}$ \\
\hline & $72 \mathrm{~h}$ & $2.85 \mathrm{~b}$ & $2.01 \mathrm{~b}$ & $3.39 b$ & $2.89 \mathrm{~b}$ \\
\hline \multirow[t]{6}{*}{$\times$ Aspect ratio } & L3 & $2.43 \mathrm{a}$ & $1.37 \mathrm{a}$ & $2.79 \mathrm{a}$ & $2.08 \mathrm{a}$ \\
\hline & L6 & $2.48 \mathrm{ab}$ & $1.75 \mathrm{ab}$ & $3.06 \mathrm{ab}$ & $2.23 \mathrm{a}$ \\
\hline & $\mathrm{L} 10$ & $2.66 \mathrm{abc}$ & $1.95 \mathrm{abc}$ & $3.32 \mathrm{bcd}$ & $2.32 \mathrm{a}$ \\
\hline & S3 & $2.81 \mathrm{abc}$ & $1.79 \mathrm{abc}$ & $3.24 \mathrm{bc}$ & $2.80 \mathrm{~b}$ \\
\hline & 56 & $2.90 \mathrm{bc}$ & $2.09 \mathrm{bc}$ & $3.51 \mathrm{~cd}$ & $2.90 \mathrm{~b}$ \\
\hline & $\mathrm{S} 10$ & $3.08 c$ & $2.43 c$ & $3.69 \mathrm{~d}$ & $3.05 \mathrm{~b}$ \\
\hline \multicolumn{6}{|l|}{ Non-depression } \\
\hline \multirow[t]{3}{*}{$\times$ Time } & $24 \mathrm{~h}$ & $1.53 \mathrm{a}$ & $0.54 \mathrm{a}$ & $1.98 \mathrm{a}$ & $2.79 \mathrm{a}$ \\
\hline & $48 \mathrm{~h}$ & $2.11 b$ & $0.88 \mathrm{a}$ & $2.44 \mathrm{~b}$ & $3.00 \mathrm{a}$ \\
\hline & $72 \mathrm{~h}$ & $2.11 \mathrm{~b}$ & $1.40 \mathrm{~b}$ & $2.51 \mathrm{~b}$ & $3.37 \mathrm{~b}$ \\
\hline \multirow[t]{6}{*}{$\times$ Aspect ratio } & $\mathrm{L} 3 \cdot$ & $1.78 \mathrm{a}$ & $0.94 a$ & $2.18 \mathrm{a}$ & $2.85 \mathrm{a}$ \\
\hline & L6. & $2.01 \mathrm{a}$ & $1.07 \mathrm{a}$ & $2.50 \mathrm{a}$ & $3.12 \mathrm{a}$ \\
\hline & $\mathrm{L} 10^{\circ}$ & $1.96 \mathrm{a}$ & $0.98 \mathrm{a}$ & $2.41 \mathrm{a}$ & $3.21 \mathrm{a}$ \\
\hline & $\mathrm{S} 3^{\circ}$ & $1.97 \mathrm{a}$ & $0.95 a$ & $2.30 \mathrm{a}$ & $2.85 \mathrm{a}$ \\
\hline & $\mathrm{S} 6^{\circ}$ & $2.00 \mathrm{a}$ & $0.78 \mathrm{a}$ & $2.28 \mathrm{a}$ & $3.07 \mathrm{a}$ \\
\hline & $\mathrm{S} 10^{\circ}$ & $1.75 \mathrm{a}$ & $0.83 \mathrm{a}$ & $2.14 \mathrm{a}$ & $3.14 \mathrm{a}$ \\
\hline
\end{tabular}

0.05) for the total sampling period. However, in ambient sediment, the percentages of males and copepodites were very similar to those of females and gravid females (1-way ANOVA revealed no significant differences, $n=5, p>0.05)$.

Time of recolonization had significant effects on all meiofauna in depression and non-depression areas. Copepods colonized much faster than nematodes. The abundance of Coullana sp. in depressions exceeded ambient sediment within 24 h (Fig. 2). For Cletocamptus deitersi, there were no significant differences in abundance between depression and ambient sediment within $48 \mathrm{~h}$ ( $t$-test, $\mathrm{n}=36, \mathrm{p}>0.1$ ). Recolonization of nematodes was very slow, and the density was only about one-fifth of ambient sediment after $72 \mathrm{~h}$. Nonsignificant treatment-time interactions for $C$. deitersi and total copepods indicated that the rates of colonization between depression and non-depression areas
Fig. 2. Mean density ( \pm standard error) at $24 \mathrm{~h}$ (sample size, $\mathrm{n}=18), 48 \mathrm{~h}(\mathrm{n}=17)$ and $72 \mathrm{~h}(\mathrm{n}=16)$ for the 2 dominant copepods, total copepods, and total nematodes in field colonization experiment. Nond: nondepression area; Depr: depression; Ambi: ambient sediment
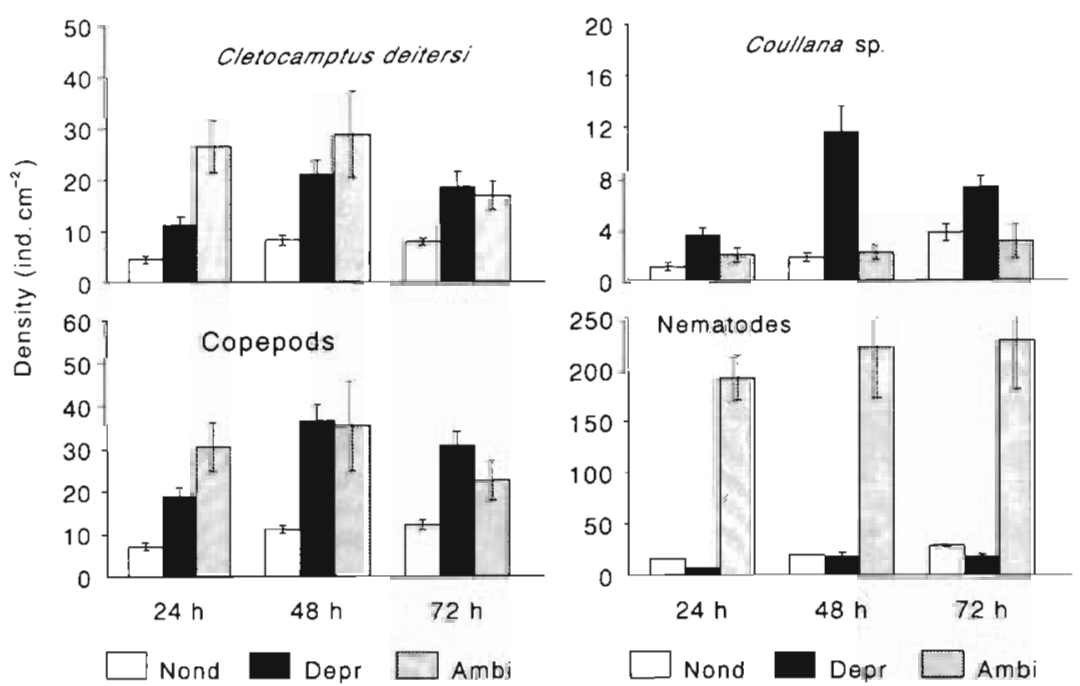


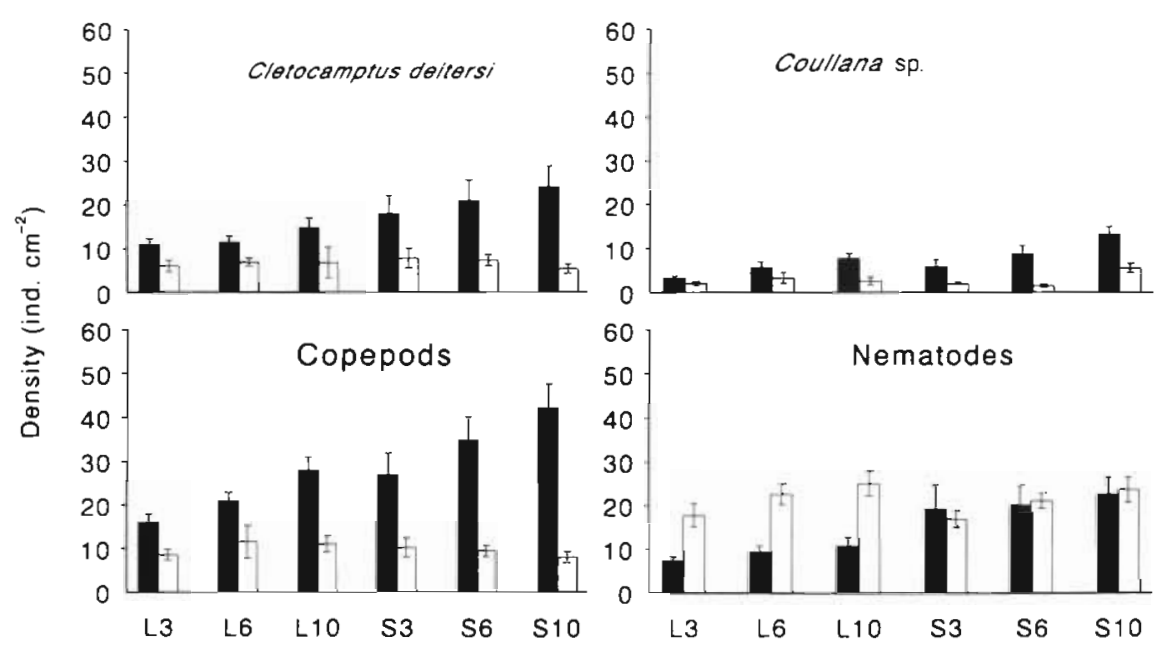

Fig. 3. Mean density ( \pm standard error, sample sizes: $L 3, \mathrm{n}=9$; L6, $\mathrm{n}=$ 8; $\mathrm{L} 10, \mathrm{n}=9 ; \mathrm{S} 3, \mathrm{n}=7 ; \mathrm{S} 6, \mathrm{n}=9 ; \mathrm{S} 10$, $n=9$ where $\mathrm{L}$ or $\mathrm{S}$ is large or small diameter vial and 3,6 , or 10 is the depth of sediment in vial) with different aspect-ratio depression and nondepression areas in field colonization study. $\square$ : Depression, $\square$ : non-depression area

were equal, while the significant treatment-time interaction demonstrated different colonization rates between depression and non-depression areas for Coullana sp. and total nematodes (Table 2, Fig. 2).

Densities of the epibenthic Cletocamptus deitersi and Couliana sp. in depressions signiticantly increased with increasing depression aspect ratio (Fig. 3, Table $3)$. The lowest aspect-ratio (larger diameter and shallowest depressions: L3) depressions were lowest in density, while the highest aspect-ratio (smaller diame-

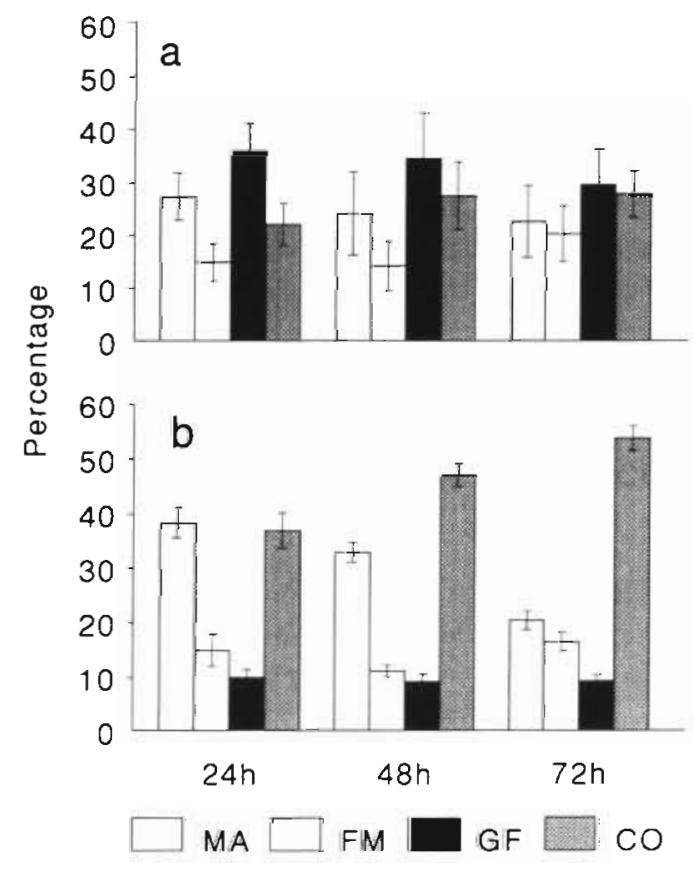

Fig. 4. Average percentage ( \pm standard error, sample sizes: ambient $\mathrm{n}=5$ and azoic $\mathrm{n}=102$ ) of different sexes and developing stages between (a) ambient sediment and (b) azoic sediment for Coullana sp. in field colonization study. MA: male; FM: female; GF: gravid female; CO: copepodite ter and deepest: S10) depressions had the highest density for both species. The significant interactions between treatment (depression vs non-depression) and aspect ratio were caused by significantly altered densities in the depressions while consistent densities in non-depression areas were observed (Tables $2 \& 3$ ).

Nematode colonization of depressions was fundamentally different compared to the epibenthic copepods. Tukey multiple comparisons indicated a significant diameter effect and the average densities in smaller-diameter depressions were about twice those in the large diameter (nematodes, Fig. 3). No density difference was detected among different aspect ratios within each depression diameter. For example, the densities in all small-diameter depressions were very similar (about 10 ind $\mathrm{cm}^{-2}$ ), as were the densities in large diameter depressions (about 20 ind. $\mathrm{cm}^{-2}$ ). The average density in S3 (20 ind. $\mathrm{cm}^{-2}$ ) was about twice that of L10 ( 11 ind. $\mathrm{cm}^{-2}$ ) even though L10 had a higher aspect ratio than \$3. Two copepod species, Pseudostenhelia wellsi (tube-dweller) and Nannopus palustris (burrower) had similar trends although their average densities were low.

\section{DISCUSSION}

Our experiment suggests that recolonization processes and abundance patterns of meiofauna depend on the interaction between the hydrodynamic regime of sediment depressions and the life style of meiofauna. The abundance patterns of epibenthic copepods in mimic depressions reflected the hydrodynamic characteristics associated with mimic depressions. The epibenthic copepods, Coullana sp. and Cletocamptus deitersi, colonized rapidly; densities in depressions were much higher ( 2 to 3 times) than those in nondepression areas and, overall, increased with increas- 
ing depression aspect ratio. The higher percentage of epibenthic males and copepodites in defaunated sediment may be a manifestation of near-bottom water entry patterns as these life history stages make more frequent forays into the water column than do females (Huys et al. 1986, Kern 1990, McCall 1992b), possibly for mating activities (Hicks 1988). Previous studies have found strong positive associations between harpacticoids and microtopographic features (Reidenauer \& Thistle 1981, Varon \& Thistle 1988, DePatra \& Levin 1989, Sun et al. 1993). On the other hand, burrowers, such as nematodes and some burrowing or tube-dwelling copepods, were much slower colonizers and did not conform to hydrodynamic predictions of settlement and abundance. Their densities were related to depression diameter (not aspect ratio), and were lower in depression than in non-depression areas.

Settlement traps are designed to estimate the number of organisms arriving at the sediment surface (Gardner 1980a, b, Butman 1986, 1989, Fegley 1988). However, our depression mimics, with low aspect ratios (from 0.09 to 0.71 ), were designed to simulate natural depressions, enhancing the comparison between meiofaunal abundance and hydrodynamic characteristics (aspect ratios) of depressions. The higher the aspect ratio of a depression, the lower the shear velocity at the bottom of depression, and vice versa (Lau 1979, Yund et al. 1991). Most natural depressions are in the range of diameters and depths of the depression mimics and have a very low depth to diameter ratio (Sun \& Fleeger 1991, Sun et al. 1993). We conducted a flume experiment using living and dead (passive) copepods to determine if our low aspect-ratio pits could collect and retain meiofauna (Fleeger, Yund \& Sun unpubl.). Results showed that initial settlement densities from the water column increased with increasing depression aspect ratio for living and dead copepods at both 5 and $8 \mathrm{~cm} \mathrm{~s}^{-1}$. Increases in the capture and retention of epibenthic copepods with increasing depression aspect ratio in our field studies could have been by active (by copepods preferring to settle in areas of lower shear stress when they fall from water column) or passive processes (by falling into depressions and being retained as if they were passive particles). The fact that dead copepods were retained in our flume studies suggests that passive processes associated with settlement from near-bottom water are likely involved although it does not necessarily exclude active processes. Nevertheless, depression aspect ratio appears to be an excellent predictor of density of epibenthic species in field depressions. Meiobenthic burrowers such as nematodes were very slow to colonize our experimental units, reaching only one-fifth of the ambient abun- dance even after 72 h. Chandler \& Fleeger (1983) found a similar result with nematode recolonization at the same site. The physical characteristics of microtopographic features appear to be poor predictors of burrower density because they are slow to enter the water column, perhaps in part due to their deeper depth distribution (Sibert 1981) and behavioral avoidance of the surface (Palmer \& Molloy 1986). No association was found between burrowers and ephemeral microtopographic features in an earlier study at the same site (Sun et al. 1993).

What, then, was the mechanism of colonization by burrowers into our depression mimics? Water-column transport for burrowers was not indicated (no aspectratio effects). The wall of the mimic depressions (made from a plastic vial) prevented burrowers from laterally crawling into depressions through defaunated sediment, although they could crawl along the sedimentwater interface and fall in. The frequency of disturbance at the sediment-water interface by wakes from small boats at this site is high. Further, our flow measurements suggest that flow rates and sediment disturbance associated with boat wakes typically exceeded that from tidal currents. Small amplitude waves such as wakes effectively resuspend and move the flocculent surface sediment on mudflats (Anderson 1972, Anderson \& Mayer 1984). These observations suggest that burrowers probably colonized during disturbanceinduced suspension events along the sediment-water interface in the flocculent layer. Fig. 5 summarizes the likely mode of entry into depressions by epibenthic and burrowing meiofauna.

\section{Epibenthic copepods}
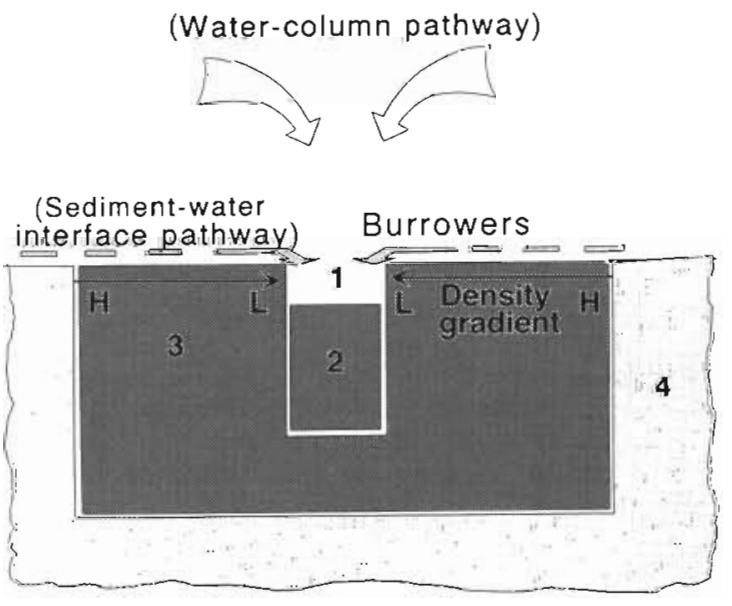

Fig. 5. A model of 2 different pathways for colonizing meiofauna into depressions: meiobenthic burrowers follow the sediment-water interface pathway; epibenthic species through a water-column pathway. (1) depression; (2) azoic sediment in depression; (3) azoic sediment in non-depression

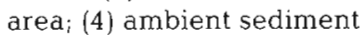


If meiobenthic burrowers disperse into depressions along the sediment-water interface, their relative abundance in depressions may also be predicted. Since dispersal occurs along the sediment surface, settlement in depressions would be related to the boundary between depression and non-depression areas. In other words, burrowers must cross the boundary of the azoic sediment surface to colonize a depression, and increases in the contact between depression and nondepression areas increase the opportunity of a burrower to enter a depression. Here, contact was a function of depression circumference $(2 \pi r$, where $r$ is the depression radius). In fact, the absolute abundance of burrowing meiofauna did increase with depression circumference. On the other hand, depression density (ind. $\mathrm{cm}^{-2}$ ) was inversely proportional to depression area $\left(\pi r^{2}\right)$. Therefore, densities in depressions were related to the ratio of circumference to area (circumference/ared $=2 \pi r / \pi r^{2}=2 / r$ ). One could predict that higher circumference/area ratios will lead to higher densities in depressions.

In this study, the circumference/area in the smalldiamcter depressions (0.286) was 2.3 times that of the large-diameter depressions (0.125). The distance between the edge of a depression and ambient sediment could be another factor that contributes to the abundance of meiofauna in a depression. For example, given identical conditions, a shorter distance between the edge of a depression and ambient sediment should allow higher abundances to be reached in the depression. Here, this distance was longer in small-diameter depressions $(3.7 \mathrm{~cm})$ than in large ones (4.6). However the distance effect was much less than the circumference to area ratio effect. This may explain why the densities in small-diameter depressions $\left(20 \mathrm{~cm}^{-2}\right)$ were about twice that of larger depressions $\left(10 \mathrm{~cm}^{-2}\right)$ regardless of aspect ratio.

However meiofauna reach sediment depressions, abundance may be altered by post-settlement activities. If flow rates are high, eddies inside the depressions can remove settled meiofauna from sediment and allow the flow to entrain and transport them away. Depressions with high aspect ratios are more likely to retain captured meiofauna. Behavior of the meiofauna may greatly influence this process. For example, some copepods are active on the sediment-water interface during times of flow, and some have been shown to actively swim into the water (Armonies 1988a, b). Such actions will tend to reduce depression densities of epibenthic meiofauna. On the other hand, as stated earlier, nematodes and burrowing copepods that enter depressions will likely burrow into the sediment to return to their natural sediment depth. Nevertheless, flow can influence this process. Palmer \& Molloy (1986) found that nematodes migrate downward when flow is present, and Foy \& Thistle (1991) reached a similar conclusion for the harpacticoid Leptastacus cf. rostratus Nicholls. Therefore, entry and post-settlement behavior are also important factors to predicting densities of meiobenthic burrowers in depressions. Such interactions between transport and behavior have not been well documented, and additional studies are needed to fully understand these interactions.

The results of this study clearly show that meiofauna of different functional groups contrast in their mechanism and ability to recruit to sediments. Hydrodynamic influences, mediated through settlement from nearbottom water, are important to epibenthic species. Pits and depressions, especially with relatively high aspect ratios, should accumulate high densities of epibenthic meiofauna. Burrowing species that are unlikely to enter the water column are slow to colonize and so do not respond to hydrodynamic influences. Such information is important when experimental studies are interpreted. Several studies (Alongi et al. 1983, Decker \& Fleeger 1984, Palmer et al. 1988, Spies et al. 1988 , Feder et al. 1990) have experimentally employed meiofaunal recruitment into sediments enriched in petroleum hydrocarbons as a measure of oil spill impacts. Slow colonization by burrowing species may not represent a hydrocarbon effect, and sampling times may be critical in the design of such studies.

Acknowledgements. We thank the Louisiana Universities Marine Consortium (LUMCON) for the use of boats and laboratory facilities. We also thank Drs K. Brown, B. Moser, D Reed and K. Carman for their advice, and 2 anonymous reviewers for their comments. This work was supported by a Graduate Student Research Grant offered by the Louisiana Universities Marine Consortium Foundation, Inc. to B.S.

\section{LITERATURE CITED}

Alongi, D. M., Boesch, D. F., Diaz, R. J. (1983) Colonization of meiobenthos in oil-contaminated subtidal sands in the lower Chesapeake Bay. Mar. Biol. 72: 325-335

Anderson, F. E. (1972). Resuspension of estuarine sediments by small amplitude waves. J. sedim. Petrol. 42: 602-607

Anderson, F. E., Mayer, L. M. (1984). Seasonal and spatial variability of particulate matter of a muddy intertidal flood front. Sedimentology 31.383-394

Armonies, W. (1988a). Hydrodynamic factors affecting behavior of intertidal meiobenthos. Ophelia 28: 183-194

A.rmonies, W. (1988b). Physical factors influencing active emergence of meiofauna from boreal intertidal sediment. Mar. Ecol. Prog. Ser. 49: 277-286

Butman, C. A. (1986). Sediment trap biases in turbulent flows: results from a laboratory flume study. J. mar. Res. 44: 645-693

Butman, C. A. (1989). Sediment-trap experiments on the importance of hydrodynamical processes in distributing settling invertebrate larvae in near-bottom waters. $J$. exp. mar. Biol. Ecol. 134: 37-88

Butman, C. A., Grassle, J. P., Webb, C. M. (1988). Substrate choices made by marine larvae setting in still water and in 
a flume flow. Nature 333: 771-773

Chandler, G. T., Fleeger, J. W. (1983). Meiofaunal colonization of azoic estuarine sediment in Louisiana: mechanisms of dispersal. J. exp. mar. Biol. Ecol. 69: 175-188

Chandler, G. T., Fleeger, J W. (1984). Tube-building by a marine meiobenthic harpacticoid copepod. Mar. Biol. 82: $15-19$

Childers, D. L., Day, J. W. Jr, Muller, R. A. (1990). Relating climatological forcing to coastal water levels in Louisiana estruaries and the potential importance of El Nino-southern oscillation events. Clim. Res. 1: 31-42

Decho, A. W., Fleeger, J. W. (1988). Microscale dispersion of meiobenthic copepods in response to food-resource patchiness. J. exp. mar. Biol. Ecol. 118: 229-244

Decker, C. J., Fleeger, J. W. (1984). The effect of crude oil on the colonization of meiofauna into salt marsh sediments. Hydrobiologia 118: 49-58

DePatra, K. D., Levin, L. A. (1989). Evidence of the passive deposition of meiofauna into fiddler crab burrows. J. exp. mar. Biol. Ecol. 125: 173-192

Eckman, J. E. (1983). Hydrodynamic processes affecting benthic recruitment. Limnol. Oceanogr. 28: 241-257

Feder, H. M., Naidu, A. S., Paul, A. J. (1990). Trace element and biotic changes following a simulated oil spill on a mudflat in Port Valdez, Alaska. Mar. Pollut. Bull. 21. $131-136$

Fegley, S. R. (1987). Experimental variation of near-bottom current speeds and its effects in depth distribution of sandliving meiofauna. Mar. Biol. 95: 183-191

Fegley, S. R. (1988). A comparison of meiofaunal settlement on the sediment surface and recolonization of defaunated sandy sediment. J. exp. mar. Biol. Ecol. 123: 97-114

Foy, M. S., Thistle, D. (1991). On the vertical distribution of a benthic harpacticoid copepod - field, laboratory, and flume results. J. exp. mar. Biol. Ecol. 53: 153-163

Gardner, W. D. (1980a). Sediment trap dynamics and calibration: a laboratory evaluation. J. mar. Res. 38: 17-39

Gardner, W. D. (1980b). Field assessment of sediment traps. J. mar. Res. 38: 41-52

Hagerman, G. M. Jr, Rieger, R. M. (1981). Dispersal of benthic meiofauna by wave and current action in Bogue Sound, North Carolina, USA. Mar. Ecol. Prog. Ser. 2: 245-270

Hicks, G. R. F. (1988). Sediment rafting: a novel mechanism for the small-scale dispersal of intertidal estuarine meiofauna. Mar. Ecol. Prog. Ser. 48: 69-80

Huys, R., Herman, R. L., Heip, C. (1986). Seasonal fluctuations in vertical distribution and breeding activity of a subtidal harpacticoid community in the Southern Bight, North Sea. Neth. J. Sea Res. 20: 375-383

Kern, J. C. (1990). Active and passive aspects of meiobenthic copepod dispersal at two sites near Mustang Island, Texas. Mar. Ecol. Prog. Ser. 60: 211-224

Kern, J. C., Taghon, G. L. (1986). Can passive recruitment explain harpacticoid copepod distributions in relation to epibenthic structure? J. exp. mar. Biol. Ecol. 101: 1-23

This article was presented by S. P. Meyers (Senior Editorial Advisor), Baton Rouge, Louisiana, USA
Lau, Y, L. (1979). Laboratory study of cylindrical sedimentation traps. J. Fish. Res. Bd Can. 36: 1288--1291

McCall, J. N. (1992a). Source of harpacticoid copepods in the diet of juvenile starry flounder. Mar. Ecol. Prog. Ser. 86: $41-50$

McCall, J. N. (1992b). Behavioral influences on predator-prey interactions between juvenile teleosts and meiofauna. Ph.D. dissertation, Louisiana State University, Baton Rouge

Palmer, M. A. (1988). Dispersal of marine mejofauna: a review and conceptual model explaining passive transport and active emergence with implications for recruitment. Mar Ecol. Prog. Ser. 48: 81-91

Palmer, M. A. (1992). Incorporating lotic meiofauna into our understanding of faunal transport processes. Limnol Oceanogr. 37: 329-341

Palmer, M. A., Gust, G. (1985). Dispersal of meiofauna in a turbulent tidal creek. J. mar. Res. 43: 179-210

Palmer, M. A., Molloy, R. M. (1986). Water flow and the vertical distribution of meiofauna: a flume experiment. Estuaries 9: $225-228$

Palmer, M. A., Montagna, P. A., Spies, R. B., Hardin, D. (1988) Meiofauna dispersal near natural petroleum seeps in the Santa Barbara Channel: a recolonization experiment. Oil Chem. Poll. 4: 179-189

Phillips, F. E., Fleeger, J. W. (1985). Meiofauna meso-scale variability in two estuarine habitats. Estuar. coast. Shelf Sci. 21: $754-756$

Reidenauer, J. A., Thistle, D. (1981). Response of a softbottom harpacticoid community to stingray (Dasyatis sabina) disturbance. Mar. Biol. 65: 261-267

Savidge, W. B., Taghon, G. L. (1988). Passive and active components of colonization following two types of disturbance on an intertidal sandflat. J. exp. mar. Biol. Ecol. 115: $137-155$

Shapiro, S. S. Wilk, M. B. (1965). An analysis of variance test for normality (complete samples). Biometrika 52:591-611

Sibert, J. R. (1981). Intertidal hyperbenthic populations in the Nanaimo Estuary. Mar. Biol. 64: 259-265

Spies, R. B., Hardin, D. D., Toal, J. P. (1988). Organic enrichment or toxicity? A comparison of the effects of kelp and crude oil in sediments of the colonization and growth of benthic infauna. J. exp. Biol. 124: 261-282

Sun, B., Fleeger, J. W. (1991). Spatial and temporal patterns of dispersion in meiobenthic copepods. Mar. Ecol. Prog. Ser 71. $1-11$

Sun, B., Fleeger, J W., Carney, R. S. (1993) Sediment microtopography and the small-scale spatial distribution of meiofauna. J. exp. mar. Biol. Ecol. 167: 73-90

Varon, R., Thistle, D. (1988). Response of harpacticoid copepods to a small-scale natural disturbance. J. exp. mar. Biol. Ecol. 118: 245-256

Yund, P. O., Gaines, S. D., Bertness, M. D. (1991). Cylindrical tube traps for larval sampling. Limnol. Oceanogr. 36: $1167-1177$

Manuscript first received: August 6, 1993

Revised version accepted: April 21, 1994 